DOI: 10.46340/eujem.2020.6.5.14

Kateryna Raputa

ORCID ID: https://orcid.org/0000-0001-9907-1260

Kyiv National Economic University named after Vadym Hetman, Ukraine

\title{
ANALYSIS OF THE DYNAMICS \\ OF STARTUPS' VENTURE FINANCING IN UKRAINE
}

\author{
Катерина Рапута

\section{АНАЛІЗ ДИНАМІКИ ВЕНЧУРНОГО ФІНАНСУВАННЯ СТАРТАПІВ В УКРАЇНI}

Київський Національний Економічний Університет імені Вадима Гетьмана, Україна

\begin{abstract}
The article considers the essence and features of startups as business entities. The content of venture financing is determined, the relevance of the use of venture capital for the development of innovative business is substantiated, the differences of venture capital from traditional investment are revealed. The specifics of venture financing of startups depending on the stage of the life cycle (investment round) are systematized. The current state of the Ukrainian market of venture financing of startups for the last 10 years is studied. The main trends and risks of venture financing of Ukrainian startups in 2020 are identified, measures to overcome them are formed. The necessity of state support to stimulate the development of startup projects is substantiated.
\end{abstract}

Keywords: venture financing, startup, venture fund, venture capital, investment round, startup financing round.

Постановка проблеми. У XXI ст. венчурне підприємництво стає невід'ємною складовою світової економіки і одним з рушійних факторів розвитку як окремих суб'єктів бізнесу, так і країн в цілому. Венчурний капітал часто є не тільки можливістю втілення інноваційних ідей в життя, але і дозволяє забезпечити фінансову життєздатність економічних інститутів, сприяє диверсифікації господарських систем, підвищує технологічний потенціал і є джерелом нових робочих місць.

Венчурне фінансування $є$ одним з різновидів інноваційної діяльності, для якої характерні, з одного боку, відносно високий комерційний ризик, а з іншого боку - можливість отримання потенційно більш високих доходів. До сфери венчурного фінансування належать новітні наукоємні галузі, зокрема електроніка, робототехніка, програмне забезпечення, фотоніка, генна інженерія, біотехнологія тварин і людини, наноіндустрія, тощо. Тобто фактично йдеться про повномасштабне освоєнні V і VI технологічних укладів.

Потреба вигідного вкладення інвестиційного капіталу з метою його зростання і диверсифікації обумовлює активізацію уваги до венчурного фінансування у стартапи - інноваційні проекти, спрямовані на швидке зростання. Україна, маючи значний інтелектуальний потенціал, пропонує світу значну кількість стартап-проектів, однак не всі вони здатні знайти необхідне фінансування для свого розвитку.

Аналіз останніх досліджень та публікацій. Питання венчурного фінансування стартапів $€$ комплексним та багатоаспектним. Зокрема, сутність та особливості стартапів як виду підприємницької діяльності досліджуються такими авторами, як С. Бланк, В. Золотова, Б. Дорф, Е.Ріс, Н.I. Ситник, тощо. Можливості використання венчурного капіталу як джерела фінансування бізнессуб'єктів вивчаються в працях А.Д. Петрашевської, Н.I. Рижикової, І.І. Смирнової, К.І. Сімакова та ін. Невід'ємною умовою дослідження практики венчурного фінансування стартапів в окремій країні є оцінка іï місця в міжнародних рейтингах (Глобальному рейтингу інновацій, рейтингу глобальної конкурентоспроможності, тощо), вивчення матеріалів міжнародних та національних консалтингових 
агенцій, профільних об’єднань (Української асоціації венчурного капіталу та приватного капіталу, Глобальної мережі компаній «Делойт», тощо) та галузевих оглядів.

Сама сфера венчурних інвестицій постійно трансформується та еволюціонує, з'являються нові формати залучення фінансування для інноваційних ідей (наприклад, у XXI ст. таким джерелом стали краудфандингові платформи). Тому, незважаючи на велику кількість досліджень, питання венчурного фінансування стартапів постійно не втрачає своєї актуальності та потребує вивчення сучасних тенденцій.

Формулювання цілей статті. Метою статті є дослідження основних концептуальних засад та практики здійснення венчурного фінансування стартапів в Україні на сучасному етапі.

Виклад основного матеріалу дослідження. Зростання попиту на високотехнологічні товари та послуги, а також підвищення технологічних стандартів у світі обумовлює потребу модернізації економіки України відповідно до глобальних тенденцій. Необхідним стає розвиток національної інноваційної системи, значущим елементом якої є підприємства, що генерують інновації, в тому числі інноваційні стартап-компанії (стартапи).

Розглядаючи сутність стартапів як суб'єктів бізнесу, американські дослідники С. Бланк та Б. Дор $\phi^{1}$ визначають їх як «тимчасові структури, які займаються пошуком відновлювальної, прибуткової і масштабованої бізнес-моделі» та відрізняється від інших компаній швидким зростанням. На принциповій новизні проектів або задач, що вирішуються стартапами, наголошує американський дослідник Е.Pic ${ }^{2}$.

Досліджуючи концептуальні основи та ключові риси стартапів, українською дослідницею H.I. Ситник ${ }^{3}$ було доповнено наведені визначення та пропонується розуміти стартап як «тимчасову організацію з високим інтелектуальним потенціалом, призначену для побудови стійкої масштабованої бізнес-моделі шляхом реалізації ідеї у вигляді інноваційного продукту». Саме для забезпечення процесу трансформації від ідеї до стійкої бізнес-моделі необхідним є отримання стартапом відповідних фінансових ресурсів.

Фінансування стартапу (не враховуючи власні кошти розробника і його команди, які переважно обмежені і недостатні для належного забезпечення), можливо двома способами - шляхом отримання кредиту або шляхом залучення інвестора. Кредит зручний тим, що, якщо вдасться його виплатити (тобто, проект виявиться успішним), фірма залишиться у власності її засновників. Однак отримання кредиту для стартапів $\epsilon$ ускладненим через відсутність належного забезпечення у формі основного або оборотного капіталу. Крім того, чим більш невизначеною та нетиповою є ідея стартапу, тим жорсткіші умови кредиту, менші його розміри, а також існує велика ймовірність відмови в кредитуванні. Тому найбільш оптимальним шляхом отримання стартапами необхідного капіталу вважається венчурне фінансування.

Вивчаючи особливості венчурного фінансування в Україні та світі, Є.Ю. Мордань, Ю.В. Відменко та Ж.О. Кобець ${ }^{4}$ наголошують на провідному місці венчурного бізнесу у світовій інвестиційній індустрії. Венчурне фінансування розглядається не тільки як засіб високоприбуткового розміщення капіталу, але і як ефективний механізм упровадження інновацій. Можливості венчурних інструментів активно використовуються світовою спільнотою для розвитку реального сектору економіки і підвищення прибутковості активів.

Принципова відмінність венчурного капіталу від традиційного інвестування, полягає в тому, що його переважно інвестують в ідею або проект з підвищеним рівнем ризику. Адресатами венчурного капіталу є венчурні фірми (зокрема - стартапи), які не зобов'язані ані виплачувати відсотки, ані повертати отримані суми. Інтерес інвестора задовольняється придбанням прав на всі новації, як запатентовані, так і безпатентні ноу-хау, та отриманням прибутку від реалізації науковотехнічних розробок. Кошти для венчурного фінансування акумулюються спеціальними фінансовими і банківськими інститутами.

\footnotetext{
${ }^{1}$ Бланк, С., Дофр, Б. (2013). Стартап: настольная книга основателя. Москва: Альпина Паблишер.

2 Рис, Э. (2014). Бизнес с нуля. Метод Lean Startup для быстрого тестирования идей и выбора бизнес-модели = The Lean Startup: How Today's Entrepreneurs Use Continuous Innovation to Create Radically Successful Businesses. Москва: Альпина Паблишер.

${ }^{3}$ Ситник, Н. І. (2016). Концептуальні основи стартапів: їх сутність і класифікація. Бізнес Інформ, 8, 64-68.

${ }^{4}$ Мордань, С. Ю., Відменко, Ю. В., Кобець, Ж.О. (2018). Венчурне інвестування в Україні та світі: сучасні тенденції та особливості розвитку. Інфраструктура ринку, 17, 391-399.
} 
Базуючись на дослідженнях А.Д. Петрашевської ${ }^{1}$, I. I. Смирнової, К.І. Сімакова ${ }^{2}$, H.I. Рижикової ${ }^{3}$, варто відзначити, що на кожному етапі життєвого циклу стартапу існує певна специфіка здійснення венчурного фінансування, залежна від ряду факторів (ступеня зрілості компанії-стартапу, типу інвесторів, які беруть участь у капіталі, мети залучення капіталу). В категоріальному апараті самих стартапів та інвесторів для визначення етапу залучення фінансування на розвиток бізнесу зазвичай використовується термін «раунд залучення інвестицій» або «раунд інвестування». Назва раунду швидко надає інформацію про стадію життєвого циклу стартапу, що є зручним як для засновників стартапів (реципієнтів ризикового капіталу), так і для інвесторів. Реципієнти одразу розуміють, до яких інвесторів доцільно звертатися, а інвестори можуть сфокусуватися на певному сегменті і не обробляти зайві заявки від нерелевантних стартапів ${ }^{4}$. Систематизація особливостей венчурного фінансування стартапів залежно від раундів інвестування представлена в табл. 1.

Переходячи до дослідження специфіки інвестування у вітчизняні стартапи, варто зазначити, що ринок України має значний потенціал для венчурного фінансування. Міжнародними рейтингами відзначається середній рівень інноваційної активності вітчизняних підприємців. Зокрема, згідно з глобальним рейтингом інновацій The Global Innovation Index 2019, Україна посіла 47 місце зі 129 країн ${ }^{5}$, а у міжнародному рейтингу сервісу Startup Ranking за кількістю стартапів Україна зайняла 43 місце з 191 країни 6 . Оцінки Індексу глобальної конкурентоспроможності 2019 р. за показником розвитку інноваційної екосистеми надають Україні 72 місце з 141 країни ${ }^{7}$.

Про активізацію вітчизняного стартап-ринку свідчить істотне зростання обсягів венчурного фінансування за останні десять років - з \$24 млн. у 2011 р. до \$510 млн. у 2019 р. (табл. 2). Особливо активним венчурне фінансування стартапів стало у 2017-2019 рр., демонструючи зростання у кілька разів в порівнянні з попередніми роками. Зокрема, у 2015 р., а потім у 2017-2018 рр. популярності набуває фінансування ранньої стадії інвестування стартапів (Growth), а у 2019 р. на цей сегмент приходиться 85,9\% венчурних інвестицій.

За кількістю угод венчурного фінансування стартапів до 2016 р. практично 80\% інвестицій надходило на «посівній» стадії, проте 32017 р. ситуація змінилася - посилюється роль комерційної таємниці і для значної кількості угод стадія інвестування не розголошується (практично половина угод у 2017-2018 рр. та 23\% угод 2019 р.).

Найбільший обсяг середнього фінансування отримують стартапи на стадії зростання (Growth). Зокрема, у 2019 р. у ТОП-10 угод на українському ринку венчурного фінансування увійшли інвестиції у зростання стартапів GitLab (\$268 млн.), Grammarly (\$90 млн.), People.ai (\$60 млн.), JiJi.ng (\$21 млн.). Інвестиції в стартапи стадії «Раунд А» були суттєво менші (до $\$ 5$ млн.) $)^{8}$.

Досліджуючи кількість угод за обсягом венчурного фінансування (рис. 1), можна зробити висновки про високу активність інвестицій в секторах фінансування «менше $\$ 100$ тис.» та «\$100-500 тис.».

\footnotetext{
${ }^{1}$ Петрашевська, А. Д., Пєнкова, К. І. (2019). Світовий досвід венчурного фінансування підприємств телекомунікаційної сфери в умовах розвитку цифрової економіки. Науковий вісник Ужгородського національного університету. Серія: Міжнародні економічні відносини та світове господарство, 23(2), 65-71. ${ }^{2}$ Смирнова, I. І., Сімаков, К. І. (2018). Венчурний капітал як джерело фінансування інноваційного підприємництва в Україні. Економічний вісник Донбасу, 3 (53), 131-135.

${ }^{3}$ Рижикова, Н. І., Накісько, О. В., Руденко, С. В. (2019). Світовий досвід підтримки і стимулювання венчурних і бізнес-ангельських інвестицій. Вісник Харківського наџіонального технічного університету сільського господарства імені Петра Василенка, 200, 62-71.

4 Золотова, В. (2020). Что такое раунды инвестиций и как они проходять. Vctr.media. $<$ https://vctr.media/raundyi-investitsiy-18269/> (2020, серпень, 10).

5 The Global Innovation Index (2019). Globalinnovationindex <https://www.globalinnovationindex.org/gii-2019-report> (2020, серпень, 10).

${ }^{6}$ Report.startupblink (2020). Startup Ecosystem Rankings. Report <https://report.startupblink.com/> (2020, серпень, 11).

${ }^{7}$ Reports Weforum (2019). Ukraine. Global Competitiveness Index 4.0. <http://reports.weforum.org/globalcompetitiveness-report-2019/economy-profiles/\#еconomy=UKR > (2020, серпень, 11).

8 Українська асоціація венчурного капіталу та приватного капіталу (2019). Інвестиції в українські стартапи y 2019: огляд українського венчурного та приватного капіталу <http://uvca.eu/ua/news/investments-intoukrainian-startups-in-2019-overview> (2020, серпень, 12).
} 
Таблиця 1

\section{Специфіка венчурного фінансування стартапів залежно від стадії життєвого циклу (раунду інвестування)}

\begin{tabular}{|c|c|c|c|}
\hline $\begin{array}{c}\text { Стадія } \\
\text { життєвого циклу } \\
\text { стартапу } \\
\text { (раунд інвестування) }\end{array}$ & $\begin{array}{c}\text { Суб’єкти венчурного } \\
\text { фінансування }\end{array}$ & Цілі фінансування & $\begin{array}{c}\text { Рівень інвестицій } \\
\text { та ризику }\end{array}$ \\
\hline $\begin{array}{l}\text { «Передпосівна» } \\
\text { стадія (Pre-seed) - } \\
\text { поява ідеї, перші } \\
\text { кроки проекту }\end{array}$ & $\begin{array}{l}\text { Переважно } \\
\text { використовуються } \\
\text { власні кошти, кошти } \\
\text { сім’̈, друзів, } \\
\text { бізнес-ангелів, гранти, } \\
\text { краудфандинг }\end{array}$ & $\begin{array}{l}\text { Перевірка гіпотези } \\
\text { бізнес-ідеї, вибір вектору } \\
\text { діяльності, перетворення } \\
\text { гіпотези у продукт }\end{array}$ & $\begin{array}{l}\text { Низький обсяг інвестицій } \\
\text { (до } \$ 100 \text { тис.) } \\
\text { Високий ризик } \\
\text { Відсіюється близько } 85 \% \\
\text { проектів }\end{array}$ \\
\hline $\begin{array}{l}\text { «Посівна» стадія } \\
\text { (Seed) - розробка } \\
\text { прототипу, } \\
\text { забезпечення його } \\
\text { відповідності } \\
\text { вимогам ринку }\end{array}$ & $\begin{array}{l}\text { Власні кошти, кошти } \\
\text { сім’ї, друзів; бізнес- } \\
\text { ангели, гранти, } \\
\text { венчурні фонди ранніх } \\
\text { стадій фінансування } \\
\text { («посівні» фонди), } \\
\text { краудфандинг, бізнес- } \\
\text { акселератори }\end{array}$ & $\begin{array}{l}\text { Фінансування досліджень, } \\
\text { розробка комерційного } \\
\text { проекту, створення } \\
\text { пілотного зразка для виходу } \\
\text { на ринок }\end{array}$ & $\begin{array}{l}\text { Середній рівень } \\
\text { інвестицій } \\
\text { (\$100 тис. - \$1 млн.) } \\
\text { Високий ризик } \\
\text { Відсіюється близько 90\% } \\
\text { проектів }\end{array}$ \\
\hline $\begin{array}{l}\text { «Рання» стадія } \\
\text { (Growth) - } \\
\text { розширення та } \\
\text { розвиток, } \\
\text { зростання }\end{array}$ & $\begin{array}{l}\text { Венчурні фонди ранніх } \\
\text { стадій фінансування, } \\
\text { класичні венчурні } \\
\text { фонди }\end{array}$ & $\begin{array}{l}\text { Підтримка розвитку бізнесу } \\
\text { та організація просування } \\
\text { на ринок продукту (сервісу) } \\
\text { протягом першого } \\
\text { комерційного випуску }\end{array}$ & $\begin{array}{l}\text { Високий рівень інвестицій } \\
\text { Високий рівень ризику }\end{array}$ \\
\hline $\begin{array}{l}\text { Стадія «експансії } \\
\text { або розширення» } \\
(\text { Раунди А, В, С) }\end{array}$ & $\begin{array}{l}\text { Венчурні фонди, } \\
\text { фонди прямого } \\
\text { інвестування, } \\
\text { банківське } \\
\text { кредитування }\end{array}$ & $\begin{array}{l}\text { Раунд А - організація } \\
\text { серійного виробництва або } \\
\text { постійна робота сервісу } \\
\text { Раунд В - масштабування } \\
\text { компанії, розширення } \\
\text { охоплення } \\
\text { Раунд С - перетворення } \\
\text { стартапу в стабільний } \\
\text { бізнес-проект, досягнення } \\
\text { прибутковості }\end{array}$ & $\begin{array}{l}\text { Високий рівень інвестицій } \\
\text { (Раунд А - від \$500 тис. } \\
\text { Раунд В - від \$1 млн. } \\
\text { Раунд С - від \$1 млн.) } \\
\text { Середній рівень ризику }\end{array}$ \\
\hline $\begin{array}{l}\text { Стадія «якісних змін» } \\
\text { (Раунд D або «вихід } \\
\text { на IPO») }\end{array}$ & $\begin{array}{l}\text { Венчурні фонди, } \\
\text { крупні інституційні } \\
\text { інвестори }\end{array}$ & $\begin{array}{l}\text { Розширення бізнесу, } \\
\text { підготовка до IPO }\end{array}$ & $\begin{array}{l}\text { Високий рівень інвестицій } \\
\text { Середній рівень ризику }\end{array}$ \\
\hline
\end{tabular}

Джерело: розроблено автором 
Таблиця 2

Стан українського ринку венчурного фінансування стартапів у 2011-2019 pp.

\begin{tabular}{|c|c|c|c|c|c|c|c|c|c|}
\hline \multirow{2}{*}{$\begin{array}{c}\text { Раунд фінансування } \\
\text { стартапу }\end{array}$} & \multicolumn{9}{|c|}{ Роки } \\
\hline & 2011 & 2012 & 2013 & 2014 & 2015 & 2016 & 2017 & 2018 & 2019 \\
\hline \multicolumn{10}{|c|}{ Сума венчурного фінансування стартапів, \$ млн. } \\
\hline Pre-seed & & & & & & & & 0,4 & 1 \\
\hline Seed & 16 & 15 & 15 & 18 & 22 & 38 & 5 & 18 & 12 \\
\hline Раунд А & 8 & 33 & 51 & 21 & 9 & & 35 & 18 & 15 \\
\hline Раунд Б & & 11 & 23 & & & 21 & & 30 & \\
\hline Growth & & & & & 101 & & 140 & 180 & 438 \\
\hline Нерозголошені & & & & & & 29 & 76 & 87 & 40 \\
\hline Інші & & & & & & & 3 & 3 & 4 \\
\hline Разом & 24 & 59 & 89 & 39 & 132 & 88 & 259 & 337 & 510 \\
\hline \multicolumn{10}{|c|}{ Кількість угод венчурного фінансування стартапів, од. } \\
\hline Pre-seed & & & & & & & & 6 & 12 \\
\hline Seed & 24 & 48 & 55 & 78 & 58 & 73 & 11 & 21 & 30 \\
\hline Раунд А & 5 & 9 & 14 & 8 & 4 & & 7 & 3 & 5 \\
\hline Раунд Б & & 1 & 2 & & & 1 & & 1 & \\
\hline Growth & & & & & 4 & & 2 & 3 & 5 \\
\hline Нерозголошені & & & & & & 13 & 41 & 49 & 26 \\
\hline Інші & & & & & & & 28 & 21 & 33 \\
\hline Разом & 29 & 58 & 71 & 86 & 66 & 87 & 89 & 104 & 111 \\
\hline \multicolumn{10}{|c|}{ Середній розмір венчурного фінансування, \$ млн./угоду } \\
\hline Pre-seed & & & & & & & & 0,07 & 0,08 \\
\hline Seed & 0,67 & 0,31 & 0,27 & 0,23 & 0,38 & 0,52 & 0,45 & 0,86 & 0,40 \\
\hline Раунд А & 1,60 & 3,67 & 3,64 & 2,63 & 2,25 & & 5,00 & 6,00 & 3,00 \\
\hline Раунд Б & & 11,00 & 11,50 & & & 21,00 & & 30,00 & \\
\hline Growth & & & & & 25,25 & & 70,00 & 60,00 & 87,60 \\
\hline Нерозголошені & & & & & & 2,23 & 1,85 & 1,78 & 1,54 \\
\hline Інші & & & & & & & 0,11 & 0,14 & 0,12 \\
\hline Разом & 0,83 & 1,02 & 1,25 & 0,45 & 2,00 & 1,01 & 2,91 & 3,24 & 4,59 \\
\hline
\end{tabular}

Джерело: складено автором за матеріалами ${ }^{1}$

\footnotetext{
${ }^{1}$ Slideshare.net (2019). Ukrainian Venture Capital and Private Equity Overview 2019. Investor Relations <https://www.slideshare.net/UVCA/ukrainian-venture-capital-and-private-equity-overview-2019-232427411?ref= http://uvca.eu/ua/news/investments-into-ukrainian-startups-in-2019-overview> (2020, серпень, 12).
} 


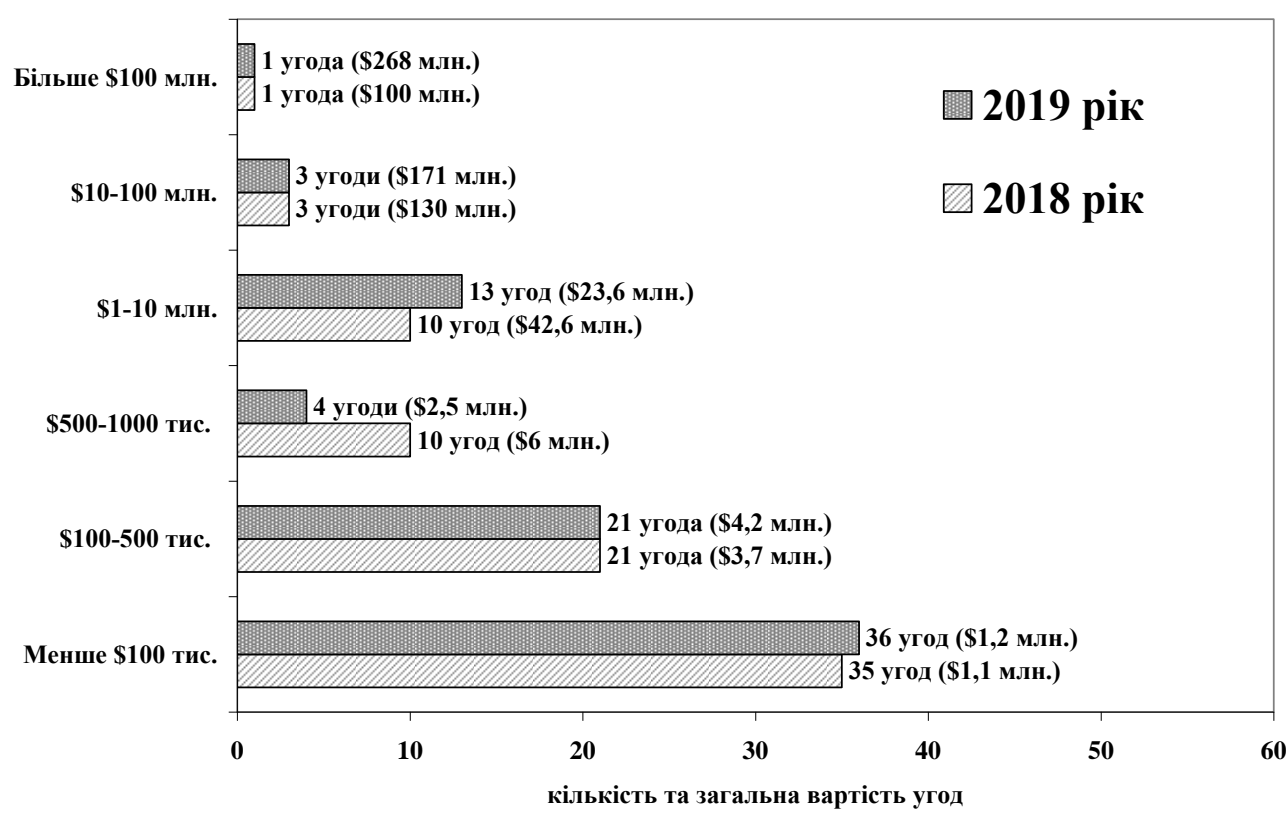

Рис. 1. Кількість та загальна вартість угод* венчурного фінансування стартапів в Україні у 2018-2019 pp.

*за виключенням угод, щуо відносяться до категорії «інші»

Джерело: ${ }^{1}$

У 2020 р., незважаючи на загрозливі тенденції в світовій та український економіці, пандемію COVID-19 та інші глобальні загрози, венчурне фінансування стартапів в Україні не зменшує обертів (табл. 3). Хоча через кризу, пов’язану з коронавірусом, деякі інвестори призупинили фінансування (зокрема, як було з компанією Allset, яка замість очікуваних \$12 млн. залучила $\$ 8,25$ млн.), стартапи продовжували розвиток та отримували фінансування як від венчурних фондів, так і від бізнес-ангелів.

Варто відзначити, що за результатами оцінок Української асоціації венчурного капіталу та приватного капіталу та Глобальної мережі компаній «Делойт», саме венчурні фонди мають стати найбільш поширених джерелом фінансування стартапів в Україні у 2020 р. (42,0\%). Частка бізнесангелів оцінюється на рівні 27,5\%, за рахунок приватного капіталу та бізнес-акселераторів може бути профінансовано відповідно близько $15,9 \%$ та $10,1 \%$ стартапів. Отримання фінансування українських стартапів за рахунок краудфандингових платформ може забезпечити до $4,3 \%$ розробок 2 .

Розглядаючи перспективи розвитку венчурного фінансування стартапів в Україні у 2020 p. Та подальші тенденції на 2021 р., важливо наголосити на значній турбулентності зовнішнього середовища та існуванні ряду ризиків, зокрема:

- очікування світової економічної кризи та нерозуміння ії глибини;

- відсутність затвердженої Програми Уряду, що могла би стати базисом для макроекономічних прогнозів;

- невизначеність з умовами введення карантинних заходів через пандемію COVID-19 осінню 2020 р.;

- можливі зміни в законодавчому регулюванні сфери стартапів (законопроект №2615);

- загальна соціальна напруга в українському суспільстві, що може стати причиною масових протестів.

\footnotetext{
${ }^{1}$ Slideshare.net (2019). Ukrainian Venture Capital and Private Equity Overview 2019. Investor Relations. $<$ https://www.slideshare.net/UVCA/ukrainian-venture-capital-and-private-equity-overview-2019-232427411?ref= http://uvca.eu/ua/news/investments-into-ukrainian-startups-in-2019-overview> (2020, серпень, 12).

${ }^{2}$ Ibid.
} 
Таблиця 3

Венчурне фінансування стартапів в Украйні у I півріччі 2020 р.

\begin{tabular}{|c|c|c|c|c|}
\hline Стартап & Коротка характеристика & Засновники & $\begin{array}{c}\text { Обсяг } \\
\text { залучених } \\
\text { коштів, } \\
\text { \$ млн. }\end{array}$ & Інвестори \\
\hline Revolut & $\begin{array}{c}\text { Британський фін-тех } \\
\text { проект }\end{array}$ & В.Яценко & 500,0 & $\begin{array}{c}\text { Венчурний фонд Теchnology } \\
\text { Crossover Ventures, японський } \\
\text { SoftBank }\end{array}$ \\
\hline Preply & $\begin{array}{c}\text { Міжнародний EdTech- } \\
\text { маркетплейс для } \\
\text { вивчення іноземних } \\
\text { мов }\end{array}$ & $\begin{array}{l}\text { С. Лук'янов, } \\
\text { Д. Волошин, } \\
\text { К. Бігай }\end{array}$ & 15,0 & $\begin{array}{l}\text { Лондонський венчурний фонд } \\
\text { Hoxton Ventures, бiзнес-ангели }\end{array}$ \\
\hline Allset & $\begin{array}{c}\text { Мобільний додаток } \\
\text { з бронювання } \\
\text { ресторанів та оплати } \\
\text { рахунку }\end{array}$ & $\begin{array}{l}\text { Г. Поліщук, } \\
\text { С. Матвієнко }\end{array}$ & 8,25 & $\begin{array}{c}\text { СБРР, Andreessen Horowitz, } \\
\text { Greycroft, SMRK VC Fund, Inovo } \\
\text { Venture Partners }\end{array}$ \\
\hline DMarket & $\begin{array}{c}\text { Монетизація } \\
\text { предметів в іграх }\end{array}$ & $\begin{array}{l}\text { В. Панченко, } \\
\text { Т. Сланова, } \\
\text { О. Кохановський }\end{array}$ & 6,5 & $\begin{array}{c}\text { Венчурний фонд Almaz Capital, } \\
\text { компанія Xsolla }\end{array}$ \\
\hline Zakaz.ua & $\begin{array}{c}\text { Он-лайн замовлення } \\
\text { та доставка продуктів }\end{array}$ & Є. Анчишкін & $\begin{array}{l}\text { 5,0 млн. } \\
\text { євро }\end{array}$ & $\begin{array}{l}\text { Венчурний фонд Chernovetskyi } \\
\text { Investment Group (CIG) }\end{array}$ \\
\hline 3DLOOK & $\begin{array}{c}\text { 3D-технології } \\
\text { сканування людини } \\
\text { за фото }\end{array}$ & В. Роговський & 5,5 & $\begin{array}{c}\text { Фінансова група ICU Ventures, } \\
\text { бізнес-ангели з США та Західної } \\
\text { Свропи }\end{array}$ \\
\hline ClassTag & $\begin{array}{c}\text { Платформа } \\
\text { спілкування батьків } \\
\text { з викладачами своїх } \\
\text { дітей }\end{array}$ & В.Лоткіна & 5,0 & $\begin{array}{c}\text { AlleyCorp, Contour Ventures, } \\
\text { Founder Collective, John Martinson, } \\
\text { Newark Venture Partners, Smart } \\
\text { Hub, TMT Investments }\end{array}$ \\
\hline Rentberry & $\begin{array}{l}\text { Сервіс в сфері } \\
\text { нерухомості }\end{array}$ & $\begin{array}{l}\text { О. Любинський, } \\
\text { Л. Остапчук, } \\
\text { О. Котовський, } \\
\text { Д. Голубовський }\end{array}$ & 4,5 & $\begin{array}{c}\text { Краудфандинговий майданчик } \\
\text { WeFunder, фонд Angel Investors } \\
\text { Marlborough, бізнес-ангели }\end{array}$ \\
\hline
\end{tabular}

Джерело: розроблено автором за матеріалами ${ }^{l}$

Проте, ефективне управління здатне будь-які глобальні загрози та негативні фактори перетворити на можливості розвитку. Так, розірвання усталених виробничих та логістичних зв'язків через карантинні заходи в рамках пандемії COVID-19, актуалізувало потребу нових сервісів, на створення яких можуть бути спрямовані стартап-розробки. Трансформація соціальних звичок та переорієнтація споживчого попиту відкриває суттєві можливості для реалізації нових ідей. В очікуванні фінансової кризи інвестори прагнутимуть диверсифікувати свої ризики, активно вкладаючи кошти як в традиційні види бізнесу, так і в нові розробки, які хоча і є високо ризиковими, проте здатні принести надвисокі прибутки.

В рамках дослідження подальшого розвитку венчурного фінансування стартапів в Україні варто окремо зупинитися на можливих змінах законодавства та напрямках державної підтримки венчурної екосистеми. Зокрема, в рамках Міністерства цифрової трансформації України наприкінці 2019 р. було створено Український фонд стартапів, яким здійснюється відбір заявок на фінансування

\footnotetext{
${ }^{1}$ Міністерство фінансів України (2020). 20 стартапів з украӥнським корінням, які залучили інвестиції у коронакризу <https://minfin.com.ua/2020/07/21/49152142/> (2020, серпень, 13); Щербань, О. (2020). Інвестиції 2020: Які українські стартапи отримали фінансування у понад \$1 мільйон. Investory.news. $<$ https://investory.news/investicii-2020-yaki-ukrainski-startapi-otrimali-finansuvannya-u-ponad-1-miljon/> (2020, серпень, 13).
} 
бізнес-ідей в розмірі до $\$ 75$ тис. (до $\$ 25$ тис. на етапі pre-seed та до $\$ 50$ тис. на етапі seed) ${ }^{1}$. Перші гранти від Кабінету Міністрів України були надані у лютому 2020 р., їх отримали 6 проектів на Seed-раундах та 2 проекти на раундах Pre-Seed2. На 2020 р. обсяг запланованого державного фінансування через Український фонд стартапів становить 440 млн. грн.3 Експерти галузі наголошують на необхідності збільшення розмірів фінансування та розширення можливості отримання інвестицій у інших раундах.

Можливі зміни в сфері законодавчого регулювання розвитку венчурного фінансування стартапів пов'язані із законопроектом №26154, метою якого задекларована податкова підтримка стартапів як нового інноваційного бізнесу. Однак на практиці, текст законопроекту є доволі «сирим», стосується фактично пільгових умова для бізнесменів-початківців, незалежно від сфери їх діяльності та нівелює саме поняття «стартапу».

Висновки та перспективи подальших досліджень. В умовах української економіки, що характеризується не сформованістю національної інноваційної системи, повільністю процесів утворення малих інноваційних компаній, недостатністю фінансових ресурсів, низькою мотивацією економічних агентів до здійснення інноваційної діяльності, венчурне фінансування покликане інтенсифікувати інноваційний розвиток за рахунок полегшення доступу стартапів до фінансових ресурсів.

Вдосконалення процесів венчурного фінансування стартапів потребує забезпечення взаємодії венчурних фондів з інноваційним бізнесом (стартапами), що може бути реалізоване за рахунок симбіозу венчурних структур з інноваційними структурами: бізнес-акселераторами, технопарками, науковими центрами, навчальними закладами, науково-дослідними установами, інкубаторами бізнесу. Запропоновані заходи дозволять сформувати гнучку структурноінвестиційну політику і забезпечити оперативний перерозподіл ресурсів з метою стимулювання розвитку стартап-проектів.

Перспективні дослідження в цій сфері повинні бути спрямовані на оцінку і розробку механізмів взаємодії українських стартапів з міжнародними та транснаціональними структурами венчурного капіталу, а також на розробку нових (гібридних) форм функціонування міжнародного венчурного капіталу в національних умовах.

\section{Referenses:}

1. Blank, S., Dofr, B. (2013). Startap: nastolnaja kniga osnovatelja [Startup: Founder's Handbook]. Moscow: Alpina Pablisher. [in Russian].

2. Inventure.com.ua (2020). Venchurnaja industrija Ukrainy: itogi 2019 goda [Venture Industry of Ukraine: Results of 2019] <https://inventure.com.ua/analytics/articles/venchurnaya-industriya-ukrainy:-itogi-2019-goda> (2020, August, 14). [in Russian].

3. Zolotova, V. (2020). Chto takoe raundy investicij i kak oni prohodjat [What are investment rounds and how do they go?]. Vctr.media <https://vctr.media/raundyi-investitsiy-18269/> (2020, August, 10). [in Russian].

4. Ukrainska asotsiatsiia venchurnoho kapitalu ta pryvatnoho kapitalu (2019). [Ukrainian Association of Venture Capital and Private Capital (2019)]. Investytsii v ukrainski startapy u 2019: ohliad ukrainskoho venchurnoho ta pryvatnoho kapitalu [Investing in Ukrainian startups in 2019: a review of Ukrainian venture and private capital] $<$ http://uvca.eu/ua/news/investments-into-ukrainian-startups-in-2019-overview> (2020, August, 12). [in Ukrainian].

5. Ministerstvo finansiv Ukrainy (2020) [Ministry of Finance of Ukraine (2020)]. Materialy Minfinu. 20 startapiv z ukrainskym korinniam, yaki zaluchyly investytsii u koronakryzu [Materials of the Ministry of Finance. 20 startups with Ukrainian roots that have attracted investment in the corona crisis].

<https://minfin.com.ua/2020/07/21/49152142/> (2020, August, 13). [in Ukrainian].

\footnotetext{
${ }^{1}$ Міністерство та Комітет цифрової трансформації України (2019). Український фонд стартапів починає прийом заявок на фінансування <https://thedigital.gov.ua/news/ukrainskiy-fond-startapiv-pochinae-priyomzayavok-na-finansuvannya $>$ (2020, серпень, 13).

2 Перція, I. (2020). Ukrainian Startup Fund - як подати заявку та отримати фінансування. Uaspectr.com. <https://uaspectr.com/2020/05/12/ukrainian-startup-fund-yak-otrymaty-finansuvannya/> (2020, серпень, 13).

${ }^{3}$ Inventure.com.ua (2020). Венчурная индустрия Украинь:: итоги 2019 года

<https://inventure.com.ua/analytics/articles/venchurnaya-industriya-ukrainy:-itogi-2019-goda> (2020, серпень, 14).

${ }^{4}$ Проект Закону про внесення змін до Податкового кодексу України щзодо встановлення спеціального податкового режиму, 2019 (Верховна Рада України). Офіційний сайт Верховної Ради Украйни <http://w1.c1.rada.gov.ua/pls/zweb2/webproc4_1?pf3511=67671> (2020, серпень, 14).
} 
6. Mordan, Ye. Yu., Vidmenko, Yu. V., Kobets, Zh. O. (2018). Venchurne investuvannia v Ukraini ta sviti: suchasni tendentsii ta osoblyvosti rozvytku. [Venture investment in Ukraine and the world: current trends and features of development]. Infrastruktura rynku [Market Infrastructure], 17, 391-399. [in Ukrainian].

7. Pertsiia, I. (2020). Ukrainian Startup Fund - yak podaty zaiavku ta otrymaty finansuvannia. [Ukrainian Startup Fund - how to apply and get funding]. Uaspectr.com <https://uaspectr.com/2020/05/12/ukrainian-startup-fundyak-otrymaty-finansuvannya/> (2020, August, 13). [in Ukrainian].

8. Petrashevska, A. D., Pienkova, K. I. (2019). Svitovyi dosvid venchurnoho finansuvannia pidpryiemstv telekomunikatsiinoi sfery $\mathrm{v}$ umovakh rozvytku tsyfrovoi ekonomiky [World experience of venture financing of telecommunication enterprises in the conditions of digital economy development]. Naukovyi visnyk Uzhhorodskoho natsionalnoho universytetu. Seriia : Mizhnarodni ekonomichni vidnosyny ta svitove hospodarstvo. [Scientific Bulletin of Uzhhorod National University. Series: International Economic Relations and the World Economy], 23 (2), 65-71. [in Ukrainian].

9. Proekt Zakonu pro vnesennia zmin do Podatkovoho kodeksu Ukrainy shchodo vstanovlennia spetsialnoho podatkovoho rezhymu, 2019 (Verkhovna Rada Ukrainy) [Draft Law on Amendments to the Tax Code of Ukraine to Establish a Special Tax Regime, 2019 (Verkhovna Rada of Ukraine)]. Ofitsiinyi sait Verkhovnoi Rady Ukrainy [Official site of the Verkhovna Rada of Ukraine] <http://w1.c1.rada.gov.ua/pls/zweb2/webproc4_1?pf3511=67671> (2020, August, 14). [in Ukrainian].

10. Ryzhykova, N. I., Nakisko, O. V., Rudenko, S. V. (2019). Svitovyi dosvid pidtrymky i stymuliuvannia venchurnykh i biznes-anhelskykh investytsii [World experience in supporting and stimulating venture and business angel investments]. Visnyk Kharkivskoho natsionalnoho tekhnichnoho universytetu silskoho hospodarstva imeni Petra Vasylenka [Bulletin of Petro Vasylenko Kharkiv National Technical University of Agriculture], 200, 62-71. [in Ukrainian].

11. Ris, Je. (2014). Biznes s nulja. Metod Lean Startup dlja bystrogo testirovanija idej $i$ vybora biznes-modeli= The Lean Startup: How Today's Entrepreneurs Use Continuous Innovation to Create Radically Successful Businesses. [Business from scratch. Lean Startup Method for Rapid Testing of Ideas and Choosing a Business Model = The Lean Startup: How Today's Entrepreneurs Use Continuous Innovation to Create Radically Successful Businesses]. Moscow: Alpina Pablisher. [in Russian].

12. Sytnyk, N. I. (2016). Kontseptualni osnovy startapiv: yikh sutnist i klasyfikatsiia. [Conceptual foundations of startups: their essence and classification]. Biznes Inform [Business Inform], 8, 64-68. [in Ukrainian].

13. Smyrnova, I. I., Simakov, K. I. (2018). Venchurnyi kapital yak dzherelo finansuvannia innovatsiinoho pidpryiemnytstva $v$ Ukraini [Venture capital as a source of funding for innovative entrepreneurship in Ukraine]. Ekonomichnyi visnyk Donbasu. [Economic Bulletin of Donbass], 3 (53), 131-135. [in Ukrainian].

14. Ministerstvo ta Komitet tsyfrovoi transformatsii Ukrainy (2019). [Ministry and Committee for Digital Transformation of Ukraine (2019)].Ukrainskyi fond startapiv pochynaie pryiom zaiavok na finansuvannia [The Ukrainian Fund of Startups starts accepting applications for funding] <https://thedigital.gov.ua/news/ukrainskiy-fond-startapiv-pochinae-priyom-zayavok-na-finansuvannya> (2020, August, 13). [in Ukrainian].

15. Shcherban, O. (2020). Investytsii 2020: Yaki ukrainski startapy otrymaly finansuvannia u ponad $\$ 1$ milion. [Investments 2020: Which Ukrainian startups received funding of over \$ 1 million]. Investory.news <https://investory.news/investicii-2020-yaki-ukrainski-startapi-otrimali-finansuvannya-u-ponad-1-miljon/> (2020, august, 13). [in Ukrainian].

16. Report.startupblink (2020). Startup Ecosystem Rankings. Report <https://report.startupblink.com/> (2020, August, 11). [in English].

17. Globalinnovationindex (2019). The Global Innovation Index <https://www.globalinnovationindex.org/gii-2019-report> (2020, August, 10). [in English].

18. Reports.weforum (2019). Ukraine. Global Competitiveness Index 4.0. 2019 edition <http://reports.weforum.org/global-competitiveness-report-2019/economy-profiles/\#economy=UKR > (2020, August, 11). [in English].

19. Slideshare.net (2019). Ukrainian Venture Capital and Private Equity Overview. Investor Relations <https://www.slideshare.net/UVCA/ukrainian-venture-capital-and-private-equity-overview-2019-232427411?ref =http://uvca.eu/ua/news/investments-into-ukrainian-startups-in-2019-overview> (2020, August, 12). [in English]. 